This item was submitted to Loughborough's Research Repository by the author.

Items in Figshare are protected by copyright, with all rights reserved, unless otherwise indicated.

\title{
Learning and teaching about race and racism in geography
}

PLEASE CITE THE PUBLISHED VERSION

https://www.e-elgar.com/shop/handbook-for-teaching-and-learning-in-geography

PUBLISHER

Edward Elgar

VERSION

AM (Accepted Manuscript)

PUBLISHER STATEMENT

This work is made available according to the conditions of the Creative Commons Attribution-NonCommercialNoDerivatives 4.0 International (CC BY-NC-ND 4.0) licence. Full details of this licence are available at: https://creativecommons.org/licenses/by-nc-nd/4.0/

\section{LICENCE}

CC BY-NC-ND 4.0

\section{REPOSITORY RECORD}

Esson, James, and Angela Last. 2019. "Learning and Teaching About Race and Racism in Geography". figshare. https://hdl.handle.net/2134/34286. 


\title{
Learning and teaching about race and racism in geography James Esson, Angela Last and the RGS-IBG RACE Working Group
}

\begin{abstract}
This chapter demonstrates how learning and teaching about race can both further understanding about racial inequality within geography, and improve disciplinary knowledge about the history and spatiality of racism as it intersects with wider structural inequalities. Through doing so, the chapter contributes to longstanding and more recent debates over how geography curricula are shaped by and perpetuate subjectivities, epistemologies and practices underpinned by racist logic. We illustrate how insights from decolonial approaches, and Critical Race Theory (CRT) perspectives, can support geographers in creating degree programs that address and counteract the perpetuation of 'white geographies' i.e. the racist and colonial assumptions that are normalised and circulated through our institutional arrangements and practices. We conclude by calling on geographers to embrace a 'curriculum against domination', which rejects learning, teaching and knowledge production that perpetuates hierarchies of superiority and inferiority. [137 words]
\end{abstract}

Key words: critical race theory; curriculum; decolonial; diversity; pedagogy; race and racism

\section{Biography}

The RGS-IBG's Race, Culture and Equality Working Group's (RGS-IBG RACE) was established in 2015, with the aim of encouraging and undertaking geographical research, curriculum development and positive action for change on issues around race and racism. James Esson is Lecturer in Human Geography in the Department of Geography and Environment at Loughborough University, and head of the RGS-IBG RACE' Learning and Teaching subcommittee. Angela Last is Lecturer in Human Geography in the Department of Geography at the University of Leicester, and Treasurer of the RGS-IBG RACE. 


\section{Section 2 \\ $<a>$ Learning and teaching about race and racism in geography RGS-IBG RACE Working Group}

\section{$<b>$ Introduction}

Many of us teach courses that are shaped by anti-colonial and antiracist scholarship...We have compelling 'how-to' stories of what it means to incorporate race, ethnicity and anti-colonial perspectives into our classrooms... But I would argue that still, with all of this, for the most part, we are writing, teaching, and recreating white geographies: by 'we' I mean almost all of us (including me); by 'white' I mean ways of seeing, understanding, and interrogating the world that are based on racialized and colonial assumptions that are unremarked, normalized, and perpetuated (Domosh, 2015).

This quote is from Mona Domosh, former President of the American Association of Geographers (AAG), in an essay provocatively titled 'Why is our geography curriculum so white?' Domosh highlights an issue that a relatively small group of geographers have spent decades trying to address, specifically; how learning and teaching in geography is shaped by and perpetuates racism (cf. Jackson 1989; Kobayashi, 1999; Mahtani, 2006). This scholarship connects to wider debates over racial oppression that transcends the discipline, and similarly Domosh's essay resonates with contemporary social movements seeking to challenge racism inside and outside the academy, for example; those asking and investigating 'Why isn't my professor black? and 'Why is my curriculum white'?; activism linked to Rhodes Must Fall in South Africa (Mbembe, 2016) and Oxford (Elliott-Cooper, 2017), and indigenous led movements such as the Standing Rock resistance to the Dakota Access Pipeline (Lane, 2017) and the Katribu resistance to mining in the Philippines (Simbulan, 2016).

While we recognise that this chapter speaks from and primarily to the Western academy, we aim to situate our contribution to this volume within the above-mentioned efforts and movements seeking to dismantle the racist social classification of the world's population. The main aim of this chapter is to provide a resource for geographers wanting to learn and teach about race and racism, it is hoped that the insights provided will help counteract the reproduction of 'white geographies' in practical as well as epistemological terms. The next section introduces key ideas for geographers wanting to learn about race and racism, this is followed by a discussion about the presence of racism within the discipline. We then engage with Critical Race Theory (CRT) perspectives and decolonial approaches to outline how 
geographers can teach about the history and spatiality of racial oppression, as it intersects with wider structural inequalities, without reproducing 'white geographies'. We conclude by calling for geographers to embrace a curriculum against domination which, as argued by De Lissovoy (2010), pushes back against the epistemic and cultural violence that underlies the politics of learning, teaching and knowledge production in modern higher education.

\section{<b> Race and racism: a global hierarchy of superiority and inferiority}

Race, i.e. the categorization of the world's human population according to markers, such as skin colour and head shape, was once considered a natural hierarchical framework for understanding differences among human beings verifiable by science (Back and Solomos, 2013). Racial sciences, such as eugenics, have been widely discredited and it is now acknowledged that racial categories and hierarchies are ideological constructions (Bressey and Dwyer, 2012). Yet the negative effects of a race based social classification of the world's population remains, most notably, in the form of racialization through the continued marking of some bodies as superior and other bodies as inferior. This results in racism, a global hierarchy of superiority and inferiority along the line of the human (Grosfoguel, 2016; Mignolo, 2014). Racism is relational and intersects with other ideological constructions, for example those connected to patriarchy and capitalism, which coalesce to generate oppressive relations around race, gender and class (cf. Crenshaw, 1989; Nayak, 2003; McKittrick, 2006; Raghuram et al. 2011; Woods, 2017).

Racism constitutes a 'metaphysical catastrophe', because it transforms the meanings associated with fundamental areas of thinking and being, particularly relations between the self and fellow human beings (Maldonado-Torres, 2018). Crucially, as noted by Grosfoguel (2016) drawing on the theorisations of Frantz Fanon and Boaventura de Sousa Santos, the people racially classified above the line of the human, as in they are fully recognised as human beings, have their humanity validated. Accordingly, they are able to enjoy better access to rights, resources, and social recognition of their subjectivities, epistemologies and spiritualities. Conversely, those people below the line of the human are racialised as subhuman or even non-human. In other words, their humanity is questioned and thereby negated. This dehumanisation means their access to rights, resources and the recognition of their subjectivities, epistemologies and spiritualities are invariably restricted or denied (the racialisation and exploitation of African people within the context of the transatlantic slave trade provides a good example of this).

A Grosfoguel-Fanon-Boaventura de Sousa Santos inspired understanding of racism allows us to avoid the reductionism of many existing definitions of racism, particularly those related 
solely to skin colour, by recognising that different histories in diverse regions of the world will result in a range of ways to mark bodies and place them on a hierarchy of superiority/inferiority along the lines of the human. Racism can be marked by colour, but also other markers such as ethnicity, language, culture and/or religion. An example to illustrate this point is colonial relations in Ireland. Grosfoguel (2016: 11) notes how the British could not construct their racial superiority over the Irish through the marker of skin colour, because in this case the colonizer and the colonized shared the same skin colour. In order to maintain a social hierarchy of superiority/inferiority along the line of the human a different marker was needed. Therefore, what appears at first glance to be a religious conflict between Protestants and Catholics is in fact a racial/colonial conflict.

The establishment of racialised power structures, ways of knowing, and ways of being, cannot be disentangled from the coming together and expansion of three ideologies as part of the post-15 $5^{\text {th }}$ century colonial-modern era. These ideologies are white supremacy, capitalism, and Eurocentrism. It is therefore important to note that while markers of difference between humans have long existed, the racialisation of these differences was a phenomenon driven by European colonialists seeking to establish degrees of being human. This was in order to position themselves as superior to the indigenous peoples they sought to subjugate (Mignolo, 2008; Walter and Butler, 2013). Martinot (2018) explains the colonialmodern era's role in establishing a racist global hierarchy of superiority and inferiority along the line of the human, and the intersectionality of indigeneity and race, as follows;

In 200 years, the indigenous population of the Caribbean region, and much of Mexico and Peru, had been decimated, and the slave trade that replenished it with Africans had become the most profitable industry in the entire Atlantic economy... Racialization occurred in different terms in the Spanish colonies than it did in the English colonies, but the purpose and effect was the same. Its purpose was to create a system of social categorization that differentiated between who could own land and who would be forced to work on it; a distinction in social category between who could define, and who was to be defined. Mere military superiority does not interiorize; for the most part, it generates resistance. A more inclusive social process is required to consolidate conquest. It involves defining juridical structures, forms of spirituality and religion, and the nature of personhood for others. It is the power to define that divests others of the power to define themselves, to lay claim to juridicality or a spirituality of their own, and eventually results in a concept of racial difference (Martinot, 2018). 
Today, the concept of race and our relations as and to racialised subjects are still constituted through social institutions, meanings and practices that while differing from those of the colonial period are still nefarious and complex. This is because racialised meanings and practices are not always easy to recognise. On the one hand, they are often opaque, normative and mundane. On the other hand, they are able to maintain hierarchies of superiority and inferiority that are intensely painful and damaging. A key reason this is possible is coloniality, by which we mean the "long-standing patterns of power that emerged as a result of colonialism, but that define culture, labour, intersubjective relations, and knowledge production well beyond the strict limits of colonial administrations" (MaldonadoTorres, 2007: 243). One of the main ways that coloniality manifests itself in society is through institutional racism, which constitutes;

'The collective failure of an organisation to provide an appropriate and professional service to people because of their colour, culture, or ethnic origin. It can be seen or detected in processes, attitudes and behaviour which amount to discrimination through unwitting prejudice, ignorance, thoughtlessness and racist stereotyping which disadvantage minority ethnic people' (McPherson, 1999: 369).

There are several working definitions of institutional racism, the earliest being from Kwame Ture/Stokely Carmichael and Charles Hamilton in the 1960s, but the definition above is particularly useful here. It acknowledges that while racism is in many cases based on a hierarchy of superiority-inferiority marked by physical attributes such as skin colour, processes of racialisation can as explained above be marked by ethnic, linguistic, religious or cultural identity also. Moreover, racism can but does not have to involve overt hostility and physical acts of violence. Rather, in the context of racism, violence is best understood as "any relation, process, or condition by which an individual or a group violates the physical, social, and/or psychological integrity of another person or group" (Bulhan, 1985: 135).

In this chapter we focus on two approaches that have emerged to address coloniality induced institutional racism. The first is a Critical Race Theory (CRT) perspective, which emerged in the US in the post-civil rights era. A CRT perspective begins with the premise that racism is an endemic feature of society, and CRT 'sets out not only to ascertain how society organizes itself along racial lines and hierarchies, but to transform it for the better' (Delgado and Stefancic, 2017: 3). This transformation requires both scholarship and activism that addresses racism as a harmful force that manifests itself through seemingly mundane relations and practices, as well as institutional racism in fields such as law and policing, education and medicine. The second response is decolonial in nature, which denotes 'efforts 
at rehumanizing the world, breaking hierarchies of difference that dehumanize subjects and communities and that destroy nature, and to the production of counter discourses, counter knowledges, counter creative acts, and counter-practices (Maldonado-Torres, 2018: 10). This decolonial imperative is not metaphorical, it entails the removal of ongoing colonial domination globally, thereby connecting moves to dismantle the racist social classification of the world population under Eurocentric world power (see Mignolo 2008) to indigenous-led demands for radical restructuring of land, resources and wealth (see Tuck and Yang, 2012).

In the discussion that follows we draw on the ideas introduced in this section, such as institutional racism, violence and coloniality, to reflect on the issue of racism within geography. We then elaborate on how insights from CRT and decolonial approaches can improve how we learn and teach about race and racism in geography.

\section{$<b>$ The presence of race and racism in geography}

Audrey Kobayashi's (2014) 'The Dialectic of Race and the Discipline of Geography' is a key resource for those seeking to understand race and racism in geography for many reasons, but two are worth highlighting here briefly i) the biographical approach adopted provides a detailed overview of how major thinkers in the discipline, particularly geographers of colour, have engaged with the concept of race from the Enlightenment through to the 2000s ii) Kobayashi points to a key, but often ignored, starting point for those wanting to learn and teach about race and racism in geography, which is to ensure there is scope within geography programs to critically reflect on how participation in the academy reinforces racialised social privilege. Therefore, in order to generate a critical understanding among students and teachers that recognises racism as a social phenomenon, geographers should not objectify racism and treat it as an issue irrelevant to the structures and practices within our discipline (Berg, 2012; Delaney, 2002; Dwyer, 1999; Esson, 2018). In other words, both students and teachers must begin efforts to learn and teach about race and racism by adopting a perspective in keeping with CRT, i.e. one that recognises the need to reflect critically on the endemic nature of racism in society and accordingly the presence of race and racism in geography. One way to do this is by interrogating the idea of the 'racial project'.

Geography as a field of study, a social institution, and a workplace, is underpinned by a 'racial project' that sought to privilege an ideology of Eurocentric-white superiority (Peake and Kobayashi, 2002). This 'racial project' was and is deeply shaped by colonialism and coloniality respectively. Readers can and should think about this in relation to their own context, but for the authors who are based in the UK the 'racial project' is apparent when we 
consider geography's role as one of the disciplines used as part of empire building and colonial endeavours. For example, British geography was directly involved with and benefited from the promotion of white supremacy as part of these activities. Bonnett summarises this situation as follows;

It is difficult to underestimate the impact the ideologies and practices of empire have had upon the imagination of British geographers. Nowhere is this impact more evident than in their approach to race. Racial differences were seen by British empire builders as one of the greatest challenges to colonial expansion. Geographers interested in issues of race saw their task as the elucidation of the hierarchy of the world's races and the provision of informed speculation on the implications of White settlement and colonial government (Bonnett, 1997: 193).

As noted previously, race is an ideological construction that varies both in its affects and effects according to geographical and historical circumstances (Jackson, 1989). Let us therefore continue with the case of British geography as an example to examine how the discipline both as a social institution and a workplace reinforces racialised social privileges. We can do so by drawing on insights from two recent articles that illustrate the profile of 'Black and Minority Ethnic (BME) students and staff in contemporary British Geography' (Desai, 2017), and the everyday experiences of racism encountered by academics racialised as non-white in a geography department (Tolia-Kelly, 2017).

Vandana Desai's (2017) article is a defining moment for discussions about racism in British higher education geography, and a useful teaching resource on this topic, because it makes plain the presence of institutional racism within the discipline and the predominance and reproduction of white privilege. Drawing on a range national data sets, Desai (2017) illustrates the marginal and precarious position of people within geography who are racialized as non-white. For example, in terms of the undergraduate student body, where nationally 21.3 per cent of all UK-domiciled first degree undergraduate students are BME, for UK geography this is only 6.3 per cent (ibid 2017:320). UK BME geography students' who are admitted onto geography programs graduate with degree results significantly below those of their white peers. 11.2 per cent of BME students attained a first and 69.5 per cent attained an upper second or better (across the three years, 2013-15) as compared with 16.9 per cent and 80.0 per cent for white students respectively (ibid, 2017:321). To be clear this situation, which is not unique to geography and is known as the 'attainment gap', has been well-researched and the disparity is not attributable to an intellectual deficit in BME students (Tatlow, 2015). See also the chapter on inclusivity in this section. 
British geography not only has a low proportion of undergraduate BME students, who leave with lower grades than their white peers, but it also fails to encourage BME students to go on to postgraduate qualifications. In the UK as a whole, 16.4 per cent of UK domiciled research postgraduate students are BME yet, when we look at a subject level it reveals that, the proportion for BME UK domiciled postgraduate students in Geography is only 4.4 per cent' (Desai, 2017:320). The situation is no better when we look at academic staff. Among all UK national staff in the UK, 8.2 per cent are BME, which is almost twice the 4.3 per cent of UK national geography staff who are BME (Desai, 2017:322). The consequences of unfavourable and unsupportive environments for BME academic staff in geography make themselves manifest in lower levels of progression in the discipline (ibid, 2017:322). In the UK as a whole 7.3 per cent of UK professors are BME, but geography at 1.4 per cent is disturbingly low.

The findings from Desai's study are brought to life in Divya Tolia-Kelly's (2017) article 'A day in the life of a geographer: lone, black, female', which illustrates how these statistics take the form of racist relations, which intersect with other ideological constructions such as gender, and that have become part of the normative architecture of institutions and practices. Notably, given the context of this chapter, Tolia-Kelly highlights how for academics racialised as non-white, teaching about race and racism can be a painful practice in predominantly white institutions where some students contribute to the reproduction of racist thinking within learning environments. To be clear, the point is not that a white academic could not find themselves in a similar position where anti-racist teachings are challenged (see for example Jackson, 1989). It is rather that as a 'lone, black, female' who is already dealing with institutional racism, being in a classroom environment where an anti-racist message is being undermined by your pupils contributes to a sense of inferiority and not belonging in the academy. The following example was used to illustrate this point;

Recently, a black academic was teaching about the myth of race based on Stuart Hall (1997) and recent debates in popular culture. The discussion was focused on the discrediting of racial science. In response, the students dismissed her argument. Their responses included 'it's proven scientifically, race does exist'. 'It is biological. Look at our skins.' Also to prove their point, students started 'Googling' for evidence while in the lecture theatre. 'Look here's the evidence!' said a throng, while looking at a sports piece arguing for recognition of biological differences between white and black runners in capacities for running (e.g. Isaksen 2013). In that space, her 
authority and expertise were placed on an equal or lesser platform to the students (Tolia-Kelly, 2017: 326).

The insights from Desai (2017) and Tolia-Kelly (2017) demonstrate why, in the context of British geography as an example, geographers need to remain attentive to the fact that racism can be seen at all levels of society including the institutions, policies and practices of higher education geography (see Jackson, 1989). Furthermore, given the inferior and marginal position of geographers of colour at undergraduate level through to faculty positions as illustrated within both papers, it becomes possible to comprehend how 'white geographies' are recreated i.e. ways of seeing, understanding, and interrogating the world that are based on racialized and colonial assumptions that are unremarked, normalized, and perpetuated (Domosh, 2015). But the two papers also confirm that if geographers want to critically reflect on race and racism then there is a 'need to extend that reflection to the classroom, a major site of antiracist struggle, where both teaching methods and the ways in which we forge relations with our students are strongly influenced by the processes of racialization that surround us' (Peake and Kobayashi, 2002: 57).

\section{$<b>$ Teaching about race and racism}

In this section we draw inspiration from CRT and decolonial approaches to put forward three themes that can help geographers seeking to teach about the history and spatiality of racial oppression, as it intersects with wider structural inequalities, without reproducing 'white geographies'

\section{$<c>1$. Know (y)our history}

One of the reasons why 'white geographies' are being perpetuated through the curriculum is because of our engagement with colonialism and empire's role in shaping how geographical knowledge, modes of learning and assessing come into being is inadequate. This might seem odd given the public disdain shown by geographers for Bruce Gilley's 2017 essay on the 'Case for colonialism' suggests that blatant colonial-white supremacist thinking, which positions Europe as intellectually and morally superior, is widely considered unacceptable. But what we are calling for geography students and teachers to do, through the theme of knowing (y)our history, is to avoid engaging in a liberal humanism that includes colonial histories in teaching merely as symbolic representations. We have to remind ourselves that even core geographical concepts, such as space, had to be wrestled from imperialist and white supremacist notions such as Lebensraum - an understanding of space used by the Nazis that denoted containment, invasion and expansion. Instead, we need to encourage 
critical reflection that both exposes the costs of Western modernity and empire in the past and challenges us to address their consequences in the present (Desai and Sanya, 2016).

To know (y)our history, is to ask 'how do we narrate the history of our respective fields and methodologies within the curriculum?' For example, in geography we teach qualitative and quantitative methods, and connect their evolution to the history of science and forms of knowledge making, including cartography. This history invariably starts with Europe, yet science was shaped through global interactions and knowledge transfer (cf. Raju, 2016). We can see these influences on the development of today's science and technology all around us: we use a Hindu-Arabic numeral system, an Egyptian calendar, Babylonian time, Chinese compasses, et cetera. Furthermore, the European intellectual scene that is narrated is often, as historian Nell Irvin Painter (2010) remarks, retrospectively racialised as one full of white blonde ancient Greeks. This is not what intellectual life looked like at the time, yet these racialised reconfigurations of knowledge production in the past provide a good example of why it is important to pay attention to how knowledge is produced and portrayed today, and to keep reminding ourselves that knowledge is always geographically as well as geopolitically shaped. As McKittrick (2011: 947) notes 'a black sense of place, black histories, and communities are not only integral to production of space, but also that the analytical interconnectedness of race, practices of domination, and geography undoubtedly put pressure on how we presently study and assess racial violence'. Furthermore, scholars research about "imagined geographies" (Said, 1993), "imagined communities" (Anderson, 1983) and "invented tradition" (Hobsbawm and Ranger, 1983) - we need to incorporate these critical perspectives into our praxis and teach with them.

Depending on where you are located, to know (y)our history will mean looking at the ground upon which you currently stand and admitting that it is territory that was violently taken from indigenous populations and settled upon by colonisers. Daigle and Sundberg (2017) give an example of how they do this on their Introductory human geography course: "We start by acknowledging our hosts, the Musqueam nation, who are the legal caretakers of this

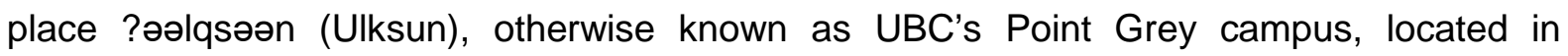
Vancouver, British Columbia" (2017: 338). This introduction skilfully introduces to students how the places that we teach, live and work today, cannot be disentangled from the above discussed colonial-modern era's role in establishing a global hierarchy of superiority and inferiority along the line of the human. Moreover, this approach invites students and teachers to see themselves as entangled in processes of colonialism irrespective of their positionality (Daigle and Sundberg, 2017), and therefore their role in maintaining racial hierarchies and structures. 
Indigenous activists and scholars have also pointed to the emphasis on particular formats of learning and assessment, and have argued that different ways of transmitting knowledge should be recognised, including different styles of written and oral history. Linda Tuhiwai Smith (2012) and Edouard Glissant (2010), for instance, highlight how indigenous forms of knowledge have been devalued as ahistorical 'traditions' or even 'natural history', that also translated into pedagogies of erasure, for instance, through compulsory and 'corrective' European education in residential schools. McCoy et al (2016) have collected experimental pedagogies that are based on the concept of "land education". Their approach critiques what they perceive as a settler imposed - and settler benefitting - education centred around "place". Smith (2012) has suggested "Twenty-Five Indigenous Projects" in her book "Decolonizing Methodologies", which include methods such from story-telling to rethinking research ethics around "sharing".

To know (y)our history is to, as Mahtani notes, 'look at sites closer to home' and ask 'are we sharing with our students how gendered and racialized identities influence who is teaching in geography, and why? (2006: 22). Who is being considered and treated as the 'norm' and who is, often by simple structural continuity, excluded? How did we arrive at the current make-up of the discipline in terms of staff and students? One consequence of knowing this history should be to critically contextualise what is included/excluded in the curriculum. This can be further reinforced by providing visual representations on slides and hand-outs of the scholars being cited. Who are we showing as victims, decision-makers, experts, workers? This is not only relevant to race, but to gender, (dis)ability et cetera, so an intersectional lens needs to be applied. Where suitable, even short biographical sketches could be included, where information is known, to show the different paths of geographers into academia. For instance, there are blog posts written by black/working class/female/disabled/LGBT+ geologists and geographers that tell their stories (e.g. the Black Geoscientists blog). These biographical sketches are not meant to represent role models, but rather to disrupt normative understandings of who is able to the enter the academy and how.

\section{$<c>2$. A place for environmental justice}

Engagement with activism in both theory and practice is relatively lacking in the geography curriculum, yet a key tenant of CRT is that we should not only aim to understand how society organizes itself along racial lines and hierarchies but try and dismantle these hierarches also (Delgado and Stefancic, 2017: 3). We appreciate that this may seem like a daunting task, but one way to approach this subject in our learning and teaching is by examining the relationship between race and environment. For example, when it comes to 'nature', geographers frequently deconstruct Western notions of the concept and its apparent 
difference from culture. Here, race often comes into play when the history of the nature/culture binary is examined. Students are sometimes told how indigenous people have been naturalised or denaturalised in accordance with imperialist and genocidal goals. What is addressed less is the contemporary white environmentalist lens. This lens has occupied environmentalists of colour who have often felt excluded by the 'white liberal' priorities that do not only treat issues that concern communities of colour as peripheral, but that also treat environmentalists of colour themselves as peripheral.

An example that shows how key geographers' engagement with race and environment are portrayed in racially biased terms is the work of the Detroit Geographical Expedition and Institute. In an interview with geographer Cindi Katz, Co-Director of the Detroit Geographical Expedition and Institute (DGEI) Gwendolyn Warren (2014) brilliantly subverts the assumptions and methods of the white geographers who wanted to involve her in a mapping project on her black neighbourhood in Detroit. Although she credits the geographers with good intentions such as equipping poor communities to bring about changes in their environment, she also calls out the naivety of the geographers about the daily living and working conditions of the community that not only shape their lives but would also hinder their participation in the project. In the case of the DGEI this included struggle with transportation, education, work and substandard living conditions. On the other hand, Warren points to the ways in which the two parties in the project were invested in making the project work for each other so that both sides could benefit in the long term: the black participants would get educational opportunities that would enable them to get university education or better work, and the white participants would learn about the shortcomings of their methods and assumptions, and be able to publish challenging work. Amongst other things, the project resulted in jointly produced maps that document how race impacts on a range of issues from road safety to housing standards.

Given that communities of colour bear the brunt of environmental hazards, summarised in the term 'environmental racism' (Bullard, 1983), there is widespread anger at white environmentalists who accuse people of colour of lacking concern for environmental issues. Sociologist Robert D. Bullard, who coined the term 'environmental racism', is considered the 'founding father' of the US environmental justice movement. By introducing race, environmentalism becomes an issue of social justice, because it calls for answers to ethical and political questions of 'who gets what, when, why and how much' (Bullard, 1999; 7). In his work, Bullard identified race as the key factor that determined how likely an American would be exposed to environmental hazards such as air, water and ground pollution (1999). This phenomenon extends beyond the United States, and also translates into relations between 
so-called 'developed' and 'developing' countries, as waste and polluting industries get pushed onto 'indebted' countries. Highlighting the impact of Bullard's work, and that of scholars and activists like him, in lectures and seminars on the environment and environmental movement would counter the impression that only white people notice and address environmental issues.

Decolonial scholarship also encourages academics to design their curriculum so that learners are made aware of the ways in which indigenous-communities of colour have been protesting against environmental abuses for centuries. Students should be introduced to research highlighting that many indigenous peoples have been relocated to land or areas that are unsuitable for maintaining their livelihoods, and that they continue to be displaced without adequate compensation or offers of the possibility to return. It is little known, for instance, that Australia and New Zealand's 'agricultural miracle', that also saw their nonagricultural landscapes transformed to a more European style, was largely dependent on fertiliser mined from islands in the Pacific such as Banaba and Nauru. On Banaba, for instance, people were forcibly moved, and did not even receive royalties. This population removal also included burial sites, which were sometimes destroyed in mining, the bones distributed as part of the fertiliser (Teaiwa, 2012: 198). Similarly, islands and islander communities were burdened with waste and radiation from nuclear weapons tests that either already have or will render their environments uninhabitable. This situation is aggravated by human induced climate change accelerating sea level rise, caused primarily by their former colonisers, which is leading to an increasingly large number of disappearing islands (Farbotko, 2010).

At the same time, a narrative of vulnerability is perpetuated that patronises local governments and activists. As writer Epeli Hau'ofa points out in his essay Our Sea of Islands: "To acknowledge the larger reality would be to undermine the prevailing view, and to frustrate certain agendas and goals of powerful interests" (1993: 14). Communities in the Pacific are fighting multiple battles that also include resources and space taken up by ongoing military occupation and imposed detention centres, and also securing space for the time in which sea level rise takes their homes. Here, Katerina Teaiwa points out the irony that the same nations that are currently refusing immigration did not have any problems spreading the 'dust of [her] ancestors' over their lands (2014: 198). Here, teaching can show how indigenous people have fought back, including legal proceedings, international campaigns, indigenous data networks, participation in global social governance (such as the UN Declaration on the Rights of Indigenous Peoples), poetry and the performing arts. These case studies not only highlight the interconnectedness of racism and environmental issues, 
but also illustrate how struggles that seem far away in space and time are connected to ongoing events and conflicts 'closer to home' (for those of us based in Europe).

\section{$<\mathrm{c}>3$. Mediating discomfort}

The final theme, 'mediating discomfort, may appear quite random. Yet it is crucial when trying to address race and racism effectively in our learning and teaching praxis. Audrey Kobayashi, in one of the few examples that exists on this theme in geography, provides telling insights on classroom dynamics on a course titled 'Race and Racism':

I am deeply aware that racism is an uncomfortable topic and that students must, in some way, face its uncomfortable realities if they are to learn and if, as I hope, they are to change. In the charged atmosphere of the classroom the shift from the intellectual to the emotional is often swift and unexpected... I feel sometimes as though I carry a bomb into class, and if I am unsuccessful in establishing the right degree of comfort (or discomfort) it will explode with irreversible results. The most important concern is that what is comfortable for some is uncomfortable for others, depending on the experiences of the individuals and groups that make up the class (Kobayashi 1999: 180).

The quote points to issues of (dis)comfort but discussing the effects of racism can also induce a mixture of anxiety, anger, confusion, frustration and in many cases guilt (cf. Dwyer, 1999; Jackson, 1989), as can the topic of ongoing colonial relations (Daigle and Sundberg, 2017). This is true both when a course/module is compulsory, and students might therefore be unprepared or reluctant to critically reflect on race related issues, and when the course/module is optional. It is important that students who have had their bodies racially marked below the line of the human and have experienced racial oppression, and might constitute the minority group within the class, should not feel objectified by their classmates and/or instructors. Kobayashi (1999) notes, however, that efforts to ensure that students never feel singled out, or obligated to share their experiences, has to be balanced with the likelihood that some students will want to share their most difficult experiences and that these personal accounts can be a 'powerful way of conveying how racism works... [and] the reality of racism in a way that no amount of reading and analysis could have done' (ibid:180).

Are there any examples of approaches that both harness the potential of voice and narrative, while alleviating the pressure on students to disclose their own experiences of racial violence? Kobayashi (1999) found that students responded positively to being provided with opportunities to use dramatizations to act out situations of everyday/subtle racism. The use 
of storytelling and counter-storytelling is a key aspect of CRT because it allows for the interrogation of myths, assumptions and stereotypes thereby subverting dominant normative and racist values (Gillborn, 2006). Peake and Kobayashi (20002) point to the potential of non-academic literature as a way to give voice to people that have experienced racism. This can also be achieved using other textual forms such as art, dance, film, and music. (see hooks, 1994). Meanwhile Daigle and Sundberg (2017: 340), as part of what they term 'an embodied and accountable pedagogical praxis', invited local community leaders and activists as well as emerging critical race scholars, to share their grounded expertise with students. This created a learning space where leaders and scholar-activists from groups that had been marginalised and 'treated as objects of analysis within academia become authorising subjects of knowledge production, autonomy and empowerment' (ibid: 340).

These approaches appear and are diverse, but what connects them is a conceptualisation of teaching and learning about race and racism as contextually situated. They simultaneously recognise the experiential knowledge of people racialised below the line of the human, and ground instructional practices in the present and past realities of students, teachers and wider society. This contextual and grounded instructional practice is a key reason why the classroom becomes a space of discomfort when teaching about race and racism in geography, because it can result in a sense of guilt amongst students. For example, many readers of this chapter will be working in settings where most students are racialised as white and at the top of a racial hierarchy. Therefore, while all participants on the program will have suffered oppression in relation to ideological hierarchies linked to for example, their gender, class and/or sexuality, the contextualisation of experiences should make it apparent that those racialised as superior live all those oppressions mitigated by racial privilege (cf. Grosfoguel 2016). Kobayashi found that this realisation and associated sense of guilt usually leads to two responses; remorse-sadness and anger-resentment (see also Jackson,1989), and argues that in both cases it is important to convey to students that their guilt related responses are neither healthy nor productive. Although challenging, teachers need to mediate this discomfort and guilt and use it productively to 'guide students towards seeing how racism and the maintenance of racial hierarchies have structured space in ways that are detrimental to almost everyone's interests' (Delaney, 2003: 12). We hope that by trying to know (y)our history and by finding a place for activism in the geography curriculum, we can start finding ways to make this happen, and dismantle these hierarchies.

\section{<b> Conclusion: a curriculum against domination}

This chapter provided a reference point for geographers seeking to learn and teach about race and racism. Significantly, by doing so, we also contributed to efforts by geographers 
striving to tackle the reproduction of 'white geographies' via geography curricula (Domosh, 2015). Central to our discussion was highlighting how pedagogies and curricula informed by insights from CRT and decolonial approaches can aid geographers to recognise the subjectivities, epistemologies and spiritualities of racially marginalised groups as part of a concerted effort to recognise and address racism. CRT and decolonial approaches insist that we must challenge the intent, form and content of our teaching as part of moves to rectify oppressive social structures in educational institutions and learning environments, as well as supporting efforts to unsettle ongoing colonial legacies (cf. Tejeda et al. 2003). Such an approach to learning and teaching would do more than just open-up counter spaces against the dominant, or create classroom conditions more welcoming to diverse perspectives, it would constitute a curriculum against domination (De Lissovoy, 2010).

A curriculum against domination is one that recognises that the decentering of the dominant content and viewpoint is not the end game. Instead, we must go further and strive to provide both staff and students with tools to begin building new ways of learning, teaching and being that are based upon coexistence and respect, as opposed to domination, separation and assimilation (De Lissovoy, 2010). A curriculum against domination appears to be what geography as a discipline is crying out for when its members ask 'why is our curriculum so white?' This chapter provided examples of key elements that could be incorporated within geography degree programmes as part of efforts to create such a framework. The more difficult task is to go from calling for change, to engaging in activism to make change happen. RGS-IBG RACE hope this chapter will be of use to those who are willing to join us and take this challenge on.

\section{$<b>$ Useful resources}

The Disorder of Things https://thedisorderofthings.com/

Global Social Theory https://globalsocialtheory.org/

Indigenous Education Network https://www.oise.utoronto.ca/ien/ 


\section{$<\mathrm{b}>$ References}

Ahmed, S. (2012). On Being Included: Racism and Diversity in Institutional Life. Durham, NC: Duke University Press.

Anderson, B. O'G. (1983). Imagined communities: reflections on the origin and spread of nationalism. London: Verso.

Back, L., \& Solomos, J. (2013). Theories of race and racism: A reader. London: Routledge.

Berg, L.D. (2012). Geographies of identity I: Geography-(neo) liberalism-white supremacy. Progress in Human Geography, 36(4), pp.508-517.

Bressey, C., \& Dwyer, C. (Eds.). (2012). New geographies of race and racism. Ashgate Publishing, Ltd.

Bulhan, H.A. (1985). Frantz Fanon and the psychology of oppression. New York:

Plenum Press.

Bullard, R. D. (ed) (1983) Confronting Environmental Racism: Voices from the Grassroots. Boston: South End Press.

Bullard, R. D. (1999). Dismantling environmental racism in the USA. Local Environment: The International Journal of Justice and Sustainability, 4(1), pp.5-19.

Césaire, S. (2012). The Great Camouflage: Writings of Dissent (1941-1945). Middletown, CT: Wesleyan University Press.

Crenshaw, K. (1989). Demarginalizing the intersection of race and sex: A black feminist critique of antidiscrimination doctrine, feminist theory and antiracist politics. University of Chicago Legal Forum 1(8), pp.139-167

Daigle, M., \& Sundberg, J. (2017). From where we stand: Unsettling geographical knowledges in the classroom. Transactions of the Institute of British Geographers, 42(3), 338-341.

Delgado, R. and Stefancic, J. (2017). Critical Race Theory: An introduction. New York University Press.

De Lissovoy, N. (2010) Decolonial pedagogy and the ethics of the global. Discourse: Studies in the Cultural Politics of Education, 31, pp. 279-293.

Desai, V. (2017) Black and Minority Ethnic (BME) student and staff in contemporary British Geography. Area, 49, pp.320-323

Delaney, D. (2002). The space that race makes. The Professional Geographer, 54(1), pp.614.

Domosh, M. (2015, June 1) Why is our curriculum so white? - Association of American Geographers Newsletter. Retrieved from http://news.aag.org/2015/06/why-is-our-geographycurriculum-so-white/ Date accessed 19/07/18

Dwyer, O. J. (1999). Teaching about race and racism in geography: Classroom and curriculum perspectives. Journal of Geography, 98(4), pp.176-179. 
Elliott-Cooper, A. (2017) 'Free, decolonised education': a lesson from the South African student struggle. Area, 49, pp.332-334.

Esson, J. (2018). 'The why and the white': Racism and curriculum reform in British Geography. Area [in press] DOI 10.1111/area.12475

Esson, J., Noxolo, P., Baxter, R., Daley, P., and Byron, M. (2017). The 2017 RGS-IBG chair's theme: decolonising geographical knowledges, or reproducing coloniality? Area, 49(3), pp.384-388.

Farbotko, C (2010). Wishful sinking: Disappearing islands, climate refugees and cosmopolitan experimentation. Asia Pacific Viewpoint 51(1), pp. 47-60.

Glissant, E. (2010). Poetics of Relation. Ann Arbor: University of Michigan Press.

Grosfoguel, R. (2016). What is Racism? Journal of World-Systems Research, 22(1), pp.9-15

Hau'ofa, E. (1993) Our sea of islands, in E. Waddell, V. Naidu and E. Hau'ofa (eds), A new Oceania: Rediscovering our sea of islands, pp. 2-16. Suva: School of Social and Economic Development, University of the South Pacific and Beake House.

Hobsbawm, E., Ranger, T. (ed.) (1983). The Invention of Tradition. Cambridge: Cambridge University Press.

hooks, b. (1994). Outlaw culture: Resisting representations. New York: Routledge.

Kobayashi, A. (2014). The dialectic of race and the discipline of geography. Annals of the Association of American Geographers, 104(6), pp.1101-1115.

Kobayashi, A. (1999). "Race" and racism in the classroom: Some thoughts on unexpected moments. Journal of Geography, 98(4), pp.179-182.

Lane, T. M. (2018). The frontline of refusal: indigenous women warriors of standing rock. International Journal of Qualitative Studies in Education, 31(3), pp.197-214.

Last, A. (2018) To Risk the Earth: The Nonhuman and Nonhistory. Feminist Review 118(1) pp. 87-92.

Mbembe, A. J. (2016). Decolonizing the university: New directions. Arts and Humanities in Higher Education, 15(1), pp.29-45.

Mahtani, M. (2014). Toxic geographies: Absences in critical race thought and practice in social and cultural geography. Social \& Cultural Geography, 15(4), 359-367.

Mahtani, M. (2006). Challenging the ivory tower: proposing anti-racist geographies within the academy. Gender, Place \& Culture, 13(1), pp.21-25.

Maldonado-Torres, N. (2007). On the Coloniality of Being: Contributions to the Development of a Concept. Cultural studies, 21(2-3), pp.240-270.

Martinot, S. (2018). The Coloniality of Power: Notes Toward De-Colonization. Retrieved at: https://www.ocf.berkeley.edu/ marto/coloniality.htm Date accessed 19/07/18 
McCoy, K., Tuck, E. \& McKenzie, M. (2016). (Eds.) Land Education: Rethinking pedagogies of place from Indigenous, postcolonial, and decolonizing perspectives. New York, NY: Routledge.

McKittrick, K. (2011). On plantations, prisons, and a black sense of place. Social \& Cultural Geography, 12(8), 947-963.

McKittrick, K. (2006). Demonic grounds: Black women and the cartographies of struggle. Minneapolis: University of Minnesota Press.

McPherson, W. (1999) The Stephen Lawrence Inquiry. Report of an Inquiry. United Kingdom: The Stationary Office. Retrieved at: https://www.gov.uk/government/uploads/system/uploads/attachment_data/file/277111/4262. pdf

Mignolo, W.D. (2008). Racism as we sense it today. Publications of the Modern Languages Association of America, 123(5), pp.1737-1742

Nayak, A. (2003). Last of the 'Real Geordies'? White masculinities and the subcultural response to deindustrialisation. Environment and Planning D: Society and Space, 21(1), pp.7-25.

Painter, N. I. (2010). The history of white people. Lodon: WW Norton \& Company.

Peake, L. and Kobayashi, A. (2002) Policies and practices for an antiracist geography at the millennium. The Professional Geographer, 54(1), pp.50-61.

Raghuram, P. Bornat, J. and Henry, L. (2011). The co-marking of aged bodies and migrant bodies: migrant workers' contribution to geriatric medicine in the UK. Sociology of Health \& Illness, 33(2), pp.321-335.

Raju, C. K. (2017). Black thoughts matter: decolonized math, academic censorship, and the "Pythagorean" proposition. Journal of Black Studies, 48(3), pp.256-278.

Said, E (1993) "Culture and Imperialism" (Lecture): York University, Toronto, February 10, 1993..

Simbulan, R. G. (2016). Indigenous Communities' Resistance to Corporate Mining in the Philippines. Peace Review, 28(1), pp.29-37.

Smith, L. T. (2012) Decolonizing methodologies: Research and Indigenous peoples (2nd ed.). New York, NY: Zed Books.

Tatlow, P. (2015) Participation of BME students in UK Higher Education in Alexander C and Arday J (eds) Aiming Higher: Race, Inequality and Diversity in the Academy London:

Runnymede pp.10-13

Tejeda, C., Espinoza, M. and Gutierrez, K., (2003). Toward a decolonizing pedagogy: Social justice reconsidered in (Ed) Trifonas, P. Pedagogies of difference: Rethinking education for social change London: Routledge.

Teaiwa, K (2014) Consuming Ocean Island: Stories of People and Phosphate from Banaba. Bloomington: University of Indiana Press. 
Tolia-Kelly, D.P., 2017. A day in the life of a Geographer: 'lone', black, female. Area, 49(3), pp.324-328.

Walter, M., \& Butler, K. (2013). Teaching race to teach Indigeneity. Journal of Sociology, 49(4), pp.397-410.

Warren, G, Katz, C (2014) Gwendolyn Warren and Cindi Katz in Conversation [video]. URL: https://vimeo.com/111159306

Woods, C. (2017). Development arrested: The blues and plantation power in the Mississippi Delta. London: Verso Books. 